REVISTA X, Curitiba, volume 13, n.1, p. 259-261, 2018.

Dossiê Especial: Português como Língua Adicional em contextos de minorias:

(co)construindo sentidos a partir das margens

BIZON \& DINIZ (Orgs.)

\title{
TRAJETÓRIA E DESAFIOS ACADÊMICOS
}

\section{Academic paths and challenges}

\section{Letícia JÔKÀHKWYJ KRAHÔ, UFG ${ }^{1}$}

Sou originária do povo Krahô, que se autodenomina de Mehi, a língua falada é o Krahô, Jê, do tronco Macro-Jê. Entretanto, somos reconhecidos como povo Timbira, e nossa área, Terra Indígena Kraolândia, está localizada no município de Goiatins (TO).

Nós Krahô, povo Mehi, acreditamos que as histórias que deram origem ao nosso povo são "verdadeiras", uma vez que as vivemos por meio dos saberes da tradição oral e da manifestação dos diversos ritos que dão origem e vida a esse povo. Minha trajetória de vida vem desse "contexto" que me é peculiar, pois nasci nessa cultura. Tenho duas irmãs, mãe mestra e coordenadora, pai foi cacique, coordenador e professor (em memória). Nasci na aldeia Galheiro. Com quatro anos mudamos para a aldeia Nova Krintuw, e, desde então, cresci juntamente com outras ahkrajrè (crianças), ouvindo e aprendendo todos os hábitos, os princípios do povo Krahô. Comecei a aprender o português na aldeia. Meus pais recebiam muitas pessoas que conversavam em português. Meu sonho era aprender a ler alguma frase, comecei a estudar e comecei a escrever mais e logo já sabia algumas palavras.

Tenho uma caminhada de vida como uma indígena que sempre valorizou os conselhos que os pais diziam. Fui uma menina "caseira", uma adolescente que com o auxílio dos meus pais tentava ler em português, porque até então só falava em mehi jarkwa. Tinha acesso a livros dos meus pais e sempre tive em pensamento ser uma pessoa "reconhecida" como meus pais; sempre admirei o respeito que as pessoas tinham por eles. Não larguei minhas raízes na aldeia, pois foi de minha família que tirei forças e coragem para mudar da comunidade para a cidade e obter conhecimentos de outra sociedade dominante não indígena. E assim ficar por perto. Sempre quis saber, ter

\footnotetext{
${ }^{1}$ Mestranda em Antropologia Social. Email: liliabram@gmail.com
} 
REVISTA X, Curitiba, volume 13, n.1, p. 259-261, 2018.

Dossiê Especial: Português como Língua Adicional em contextos de minorias:

(co)construindo sentidos a partir das margens

BIZON \& DINIZ (Orgs.)

conhecimento de onde viemos, qual nossa origem, porque viemos parar aqui nessa situação, nesse estado. São muitos motivos que me fazem cada vez mais me interessar e investigar as fontes sobre o povo Krahô, ao qual eu pertenço. Sou curiosa sobre esse tema. Na aldeia, sempre em momentos oportunos, faço perguntas sobre nossos mitos de nossa origem, para os mais velhos que são nossos sábios. Temos que ter boas memórias porque nossas comunicações não são escritas e sim orais. Por isso sempre procurei estudar.

Comecei a estudar na aldeia tardiamente, logo fui estudar em um centro de treinamento só para os indígenas, chamado Pinxwyj Hempejxá, em Carolina (MA), que tem o apoio do CTI - Centro de Trabalho Indigenista. Tive muito contato com outros parentes, como os Canela, Gavião, Krikati e Apinajé. Desde então, não parei de estudar. Na minha aldeia, a grade escolar vai até o nono ano. É uma escola com pouca estrutura, não tem energia elétrica. Por conta disso, tive que mudar para a cidade de Goiatins, a $70 \mathrm{~km}$ da Aldeia Nova, para terminar o Ensino Médio e, com muitas dificuldades, concluí.

Em 2010, perdemos o nosso pai, um exemplo de pessoa. Não tive condições de fazer mais nada. Um bom tempo depois fiz vestibular para História, na Universidade Federal de Tocantins (UFT), e fui aprovada. Foi uma nova jornada na minha vida morar longe de minha família, mas estava feliz por estar numa faculdade cursando História.

Assim que ingressei na UFT, me deparei com muitos obstáculos e dificuldades. Primeiro tive que me adaptar ao local, longe de minha família, da minha cultura, o modo de vida era diferente, muito barulho na cidade. Você anda com medo na cidade. Todo um conjunto que não fazia parte do meu convívio. $\mathrm{Na}$ faculdade, todas as disciplinas eram difíceis, teorias complexas, pois o português é minha segunda língua, mas tive a sorte de encontrar pessoas que puderam me ajudar a esclarecer as minhas ideias em relação aos textos. Fui informada pelos colegas que ia ter provas para seleção de estudantes indígenas no PET - Programa de Educação Tutorial. Eu fiz e passei no PET INDÍGENA. Comecei a trabalhar nesse projeto, no qual adquiri muitos conhecimentos de outros povos que faziam parte do projeto, como os Karajá, Xerente, e Atikum. 
R E V IS T A X, Curitiba, volume 13, n.1, p. 259-261, 2018.

Dossiê Especial: Português como Língua Adicional em contextos de minorias:

(co)construindo sentidos a partir das margens

BIZON \& DINIZ (Orgs.)

Nas minhas férias, sempre estava na aldeia com meus parentes. Gosto muito de ouvir história dos mais velhos, fazer perguntas para eles, enfim, nunca fiquei longe da minha comunidade e tenho muito orgulho dessa cultura que ainda preserva seus costumes, crenças e princípios.

O povo Krahô tem seu passado difícil. Por conflitos com os não-indígenas, perdemos muitos dos nossos familiares, sofremos massacres, mas mesmo assim resistimos até hoje.

Cinco anos depois de entrar na faculdade, me formei, e, por influências de minha mãe, me interessei em fazer inscrição no Mestrado da Universidade Federal de Goiás (UFG). Passei em todos os processos e mais uma vez fui morar ainda mais longe da comunidade, mas feliz por continuar estudando e obtendo conhecimentos e aprendizados.

Sou mestranda no Programa de Pós-Graduação em Antropologia Social da UFG e utilizarei os mitos do meu povo no meu trabalho de pesquisa, pois acredito ser de muita importância para a manutenção e fortalecimento da cultura.

Continuam as dificuldades na cidade para eu me manter na vida acadêmica, por vários motivos: financeiros, familiares, preconceitos, adaptação, enfim, motivo é o que não falta para uma desistência. Mas se temos interesse em ser uma pessoa que represente nossa comunidade e nossa cultura, não pensamos duas vezes em deixar a comunidade e ir viver com os cupês (não indígenas) na cidade. Nessa caminhada, temos muito para conquistar ainda. Existem muitos desafios a enfrentar, mas juntamente com nosso esforço, a comunidade sempre seguiu com fé nos direitos para os indígenas que buscam nas faculdades um melhor ensino e respeito. A universidade é um lugar no qual você aprende a ter uma visão diferente do comum, abre espaço aos novos desafios. Ainda são poucos os espaços destinados aos indígenas, mas com luta já tivemos “portas” abertas e apoios para alguns projetos e extensão.

Portanto, as oportunidades aos Mehi pelas universidades são aquelas que não podemos deixar "passar", pois são oportunidades de nós mostrarmos nossas culturas, nossos conhecimentos. E assim ajudamos nossas comunidades que, atualmente, estão em situações vulneráveis, com problemas provenientes das sociedades dominantes. 